\title{
SHERWOOD EDDY, THE MISSIONARY ENTERPRISE, AND THE RISE OF CHRISTIAN INTERNATIONALISM IN 1920S AMERICA*
}

\author{
MICHAEL G. THOMPSON
}

Department of History and US Studies Centre, University of Sydney

E-mail: michael.thompson@sydney.edu.au

\begin{abstract}
By tracing the career of influential YMCA missionary Sherwood Eddy, this essay brings to light the origins of Christian internationalism in 1920 s America. Far more than mere boosterism for Woodrow Wilson's League of Nations, and far more than mere "pacifism" or Social Gospel "idealism"(reductive categories with which activism in the period is often associated), Christian internationalism in the interwar period was a movement defined by three broad and far-reaching impulses. First, it was characterized by the proliferation of new enterprises such as travelling seminars, conferences and publications devoted to reflection on the ethics of international relations. Second, it comprised a holistic, oppositional and radical political orientation that went beyond legalist internationalism and encompassed agitation against imperialism and racism. Third, the movement was premised on a fundamental critique of the idea of America as a "Christian nation". Eddy's career highlights the unique importance of the missionary enterprise in giving shape to these impulses in the 1920 s and beyond.
\end{abstract}

Not the yellow peril, but the "white peril", was the real problem in world affairs, declared Sherwood Eddy, one of America's prominent missionary internationalists of the 1920s. In his official capacity as the American YMCA's travelling secretary to Asia, Eddy was addressing the leadership of the Student Volunteer Movement (SVM) — still at the time, despite some decline, one of the largest and most significant organizations mobilizing missionaries from North

For their valuable comments, criticisms and suggestions throughout the process of researching and writing this essay, I would like to thank Nikki Thompson, Stephen Robertson, Clare Corbould, Glenda Sluga, Neville Meaney, Paul Kramer, Ian Tyrrell, David Hollinger, and the editors and anonymous readers at Modern Intellectual History. Support for this research was provided by the United States Studies Centre at the University of Sydney. 
America. ${ }^{1}$ As the de facto missions arm of the YMCA and YWCA, the SVM had played a central role in the great missionary boom of the high imperial era before the First World War, but the post-war generation of leaders were brandishing new attitudes, new questions and new ideas about the validity of the missionary enterprise itself. ${ }^{2}$ A leading spokesman in this new missionary moment of "selfcriticism," Eddy crystallized the sentiment of many in his audience. " "It seems like hypocritical cant to speak of 'the white man's burden,' the so-called 'yellow peril,' the brown or black peril", when the white peril was responsible for "the landgrabbing, the economic imperialism, the military exploitation and the colonial subjugation of peoples in the interests of a supposedly 'superior' white race". ${ }^{4}$ Eddy's use of "white peril" - a term which went at least as far back as fellow missionary Sidney Gulick's 1908 work by that name-signalled his place among a generation of liberal Protestant missionaries who returned home to interpret America's role in world affairs. ${ }^{5}$ The discursive practices and political orientation of missionaries-turned-internationalists like Sherwood Eddy formed the seedbed for the growth of a new intellectual and social movement in interwar America, one we can best call Christian internationalism.

Far more than mere boosterism for Woodrow Wilson's League of Nations and far more than mere "pacifism" or Social Gospel "idealism" (reductionist categories which reflect the influence of Reinhold Niebuhr's polemics), Christian internationalism in the interwar period was a movement defined by three broad and far-reaching impulses. First, as a movement of thought it was characterized by the proliferation of a raft of new kinds of enterprise devoted to producing Christian reflection on the ethics of "international relations" world conferences, travelling seminars, print and periodical culture, ecumenical study commissions and more. Second, it consisted of a holistic, oppositional and

1 On the SVM, see Michael Parker, The Kingdom of Character: The Student Volunteer Movement for Foreign Missions, 1886-1926 (Lanham, MD, 1998).

2 As well as Parker, see Nathan D. Showalter, The End of a Crusade: The Student Volunteer Movement for Foreign Missions and the Great War (Lanham, MD, 1997).

3 For the importance of "self-criticism" and self-interrogation in ecumenical Protestantism I am indebted to David Hollinger's work. See, for example, David Hollinger, "After Cloven Tongues of Fire: Ecumenical Protestantism and the Modern American Encounter with Diversity", Journal of American History, 98/1 (June 2011), 21-48. Hollinger notes Martin Marty's earlier use of the term at 26.

4 G. Sherwood Eddy, "Present Day Social and Intellectual Unrest", address to the Student Volunteer Movement, 1924, cited in Rick L. Nutt, The Whole Gospel for the Whole World: Sherwood Eddy and the American Protestant Mission (Macon, GA, 1997), 189. For another, earlier example of Eddy using the phrase "white peril", see "Look to America for Missionaries", New York Times, Apr 10, 1916, 6.

5 Sidney L. Gulick, The White Peril in the Far East: An Interpretation of the Significance of the Russo-Japanese War (New York, 1905). 
radical political orientation that went far beyond the issues of peace versus war, or pacifism versus realism. Christian internationalists of both pacifist and realist stripes (and the stripes only became fully apparent in the late 1930s) together sought to agitate against the influences of American capitalism, imperialism, nationalism and racism in world affairs; in other words, they inveighed against the "white peril". Third, as an ideological foundation to the above factors, interwar Christian internationalism articulated a self-conscious critique of the idea of America as a "Christian nation"-long the dominant lens through which Protestants had construed American foreign policy.

By tracing out the career of Sherwood Eddy as he transitioned from missionary to full-time internationalist in the 1920s and 1930s, this essay demonstrates how each of these three characteristics was deeply connected to the missionary movement, and needs to be seen as such. Eddy became a missionary for the YMCA in 1896, officially remaining so until retirement in 1931. But in the 1920 s Eddy added to and adapted his missionary work to become something new altogether: a self-appointed, professional internationalist_-or "World TravelerReligious Statesman-Author-Speaker", as one advertisement billed him. ${ }^{6}$ His internationalist enterprises of the 1920s, including his famous annual "Traveling Seminar", through which a generation of radical and liberal Protestants such as Reinhold Niebuhr, Kirby Page and Charles Clayton Morrison gained experience of post-war Europe, gave considerable institutional shape and leadership to the wider Christian internationalist movement. And although he committed to pacifism in the 1920 s (before later renouncing that stance in World War II), Eddy's work was much more than a crusade against war. In partnership with colleagues in the movement he sought to generate awareness of and opposition to racial inequality abroad and at home, and opposition to American and Western imperialism in its informal as well as formal guises. In an age of post-Wilsonian isolationist disillusionment, he used his missionary credentials to take the lead in attempting to foster an "international mindset" among other shapers of liberal Protestant thought and culture. With one foot in the missionary enterprise, and with an extensive set of contacts and relationships with emerging indigenous Christian leaders from around the world, Eddy propagated the missionary critique of the idea of the Christian nation, insisting instead on an interracial, international and ecumenical solidarity of humankind, all the while preaching a liberal evangelical gospel of the supremacy of Jesus Christ.

Pamphlet, "University of North Carolina Y.M.C.A. Presents Sherwood Eddy in Six Public Addresses", in Box 6, Folder 114, George Sherwood Eddy Papers (Record Group No 32) Special Collections, Yale Divinity School Library, from here on referred to as the "Eddy Papers". 
Both the origins and character of interwar Christian internationalism have been obscured from view by certain reigning preoccupations in existing scholarship. One example is the way that studies of religion and foreign relations have long given overwhelming attention to Christian nationalism. Scholars have clustered around case studies that demonstrate Protestantism's role in offering a legitimating ideology for US expansionism-Wilson's “war for righteousness”, or Christian nationalism in the Truman era, for example-and have subjected the interwar years to relative neglect. ${ }^{7}$ A second related example concerns missions and imperialism. As Andrew Preston has noted, "If any topic in the history of American foreign relations has had its religious aspects thoroughly examined it is the role played by Christian missionaries in the turn to formal imperialism in the late nineteenth and early twentieth centuries." ${ }^{8}$ Much of the tone of such scholarship has reflected Emily Rosenberg's characterization of Protestant missionaries as "cultural expansionists". 9 Thus missionaries come to the fore at the obvious imperial moments of turn-of-the-century American expansionism, only to disappear after about 1920. Frank Ninkovich's survey of the US and imperialism, for example, treats the "progressive anti-imperialists" of the $1920 \mathrm{~s}$ as an entirely separate topic of discussion to imperialistic missionaries in China in earlier years; the two apparently do not connect. But in actual fact, Sherwood Eddy and many other missionaries of his ilk belonged to both eras, and need to be seen so if the contours of missionary-based anti-imperialism are to be brought to light. ${ }^{10}$

Counter to this tendency, there has been a small but growing move among a number of scholars to problematize the simple relation between missions and empire. Some, such as Brian Stanley, have rightly noted the relative neglect of studies of missions in the mid-twentieth century, the period of nationalism and decolonization, and have begun to make contributions aimed at redressing the

7 For example, see Richard M. Gamble, The War for Righteousness: Progressive Christianity, the Great War, and the Rise of the Messianic Nation (Wilmington, DE, 2003). John Fousek, To Lead the Free World: American Nationalism and the Cultural Roots of the Cold War (Chapel Hill, NC, 200o). Dianne Kirby, Religion and the Cold War (Houndmills, Basingstoke, 2003). William Inboden, Religion and American Foreign Policy, 1945-1960: The Soul of Containment (Cambridge, 2008).

8 Andrew Preston, "Bridging the Gap between the Sacred and the Secular in the History of American Foreign Relations”, Diplomatic History, 30 (Nov. 2006), 783-812, 803, 804 n.

9 Emily S. Rosenberg, Spreading the American Dream: American Economic and Cultural Expansion, 1890-1945 (New York, 1982), 28-33. Compare Arthur Schlesinger Jr, "The Missionary Enterprise and Theories of Imperialism", in John K. Fairbank, ed., The Missionary Enterprise in China and America (Cambridge, MA, 1974), 336-73.

10 Frank Ninkovitch, The United States and Imperialism (Malden, 2001), 160-63, 222-7. 
lack. ${ }^{11}$ Jon Davidann's research into the American YMCA missionary experience in Japan argues for a model of "dialogic" mutual exchange rather than unilateral expansion-an approach that captures an important dynamic by which interwar ecumenism grew out of the missionary enterprise. ${ }^{12}$ Elsewhere, a steady trickle of works on the missionary enterprise's impact on missionaries themselves, from Paul Varg's Missionaries, Chinese, and Diplomats, through Lian Xi's Conversion of Missionaries, to Grant Wacker's account of Pearl Buck's life, have done much to complicate the simple equation between missions and imperialism by examining the changes wrought on missionaries, their families and their senders. ${ }^{13}$ But much more remains to be done on linking missionaries to the substantive, developed politics of the interwar period. It was not just that missionaries underwent changes in themselves; with their new ideas, sensibilities and outlooks they aimed at impacting the wider Protestant establishment, and, beyond that, American culture and politics at large.

Another scholarly preoccupation that has helped obscure the wide-ranging, ambitious character of interwar Christian internationalism has been the interest in retelling the story of Reinhold Niebuhr's development in terms that reify the dyad of realism and pacifism. This realist grid, an adoption by historians of a category developed in the historical period, overnarrates the difference between realists and erstwhile opponents, reducing them either to being pacifists (a single issue, which ignores the breadth of their project), or to being "liberals" or "idealists" (meant pejoratively, and in the sense of being detached from political reality). Such terms of realist critique, which arose largely out of the persuasiveness of Niebuhr's own polemical writings and from contemporary historians such as E. H. Carr, went on to become controlling categories for many historians. ${ }^{14}$ In

$11 \quad$ Brian Stanley, "Christianity and the End of Empire", in Brian Stanley and Alaine M. Low, eds., Missions, Nationalism, and the End of Empire (Grand Rapids, MI, 2003), 1-14.

12 Jon Thares Davidann, A World of Crisis and Progress: The American YMCA in Japan, 1890-1930 (Bethlehem, PA, 1998), 24-8.

13 Paul A. Varg, Missionaries, Chinese, and Diplomats; The American Protestant Missionary Movement in China, 1890-1952 (Princeton, NJ, 1958). Lian Xi, The Conversion of Missionaries: Liberalism in American Protestant Missions in China, 1907-1932. (University Park, PA, 1997). Grant Wacker, "Pearl S. Buck and the Waning of the Missionary Impulse", Church History, 72/4 (2003), 852-74.

14 Similar critiques have been made by Cecelia Lynch in Beyond Appeasement: Interpreting Interwar Peace Movements in World Politics (Ithaca, NY, 1999); and by David Hollinger in "The Realist-Pacifist Summit Meeting of March 1942 and the Political Reorientation of Ecumenical Protestantism in the United States", Church History, 79/3 (Sept. 2010), 654-77. Donald Meyer's The Protestant Search for Political Realism, 1919-1941, 2nd edn (Middletown, CT, 1988), is a classic example of a narration of interwar Christian internationalism that takes realism as a controlling category. See chap. 14, "Reinhold Niebuhr, Religion and Politics", especially. 
accepting and propagating these terms, scholars have tended to miss the wider shape, scope and significance of Christian internationalism in the interwar years. In this sense, Eddy's trajectory cuts across the narrative of realism's awakening from the primordial darkness of pacifism. While it is true that Eddy did eventually agree with, and adopt, Niebuhr's critique of pacifism in the years around World War II, such a turn was epiphenomenal to the character of his internationalism. Indeed, one implication of re-examining Christian internationalism in its original breadth is that it reframes realism as one subset of a wider movement-a qualification from within.

The use of the term "Christian" internationalist is not intended here to imply a greater membership than this movement actually had. Christian internationalism was largely, but not entirely, liberal Protestant in its base, with a notable Quaker influence through related peace organizations such as the Fellowship of Reconciliation. Absent from the following narrative are Catholic Christians and conservative evangelical Christians-or, in the parlance of the 1920s, "fundamentalists". Further work could indeed be done on parallel efforts among American Catholic organizations. For instance, the Catholic Association for International Peace, founded around 1926, aimed to help Catholic Americans in "ascertaining more fully the facts of international life". Dan McKanan's work has brought to light the important contribution of peace activist Dorothy Day in the 1930 s and 1940s. ${ }^{15}$ But relative to the size and influence of Protestant groups in the 1920 s such groups were marginal and, moreover, did not share with Protestants the institutional basis in missionary sending agencies. Conservative evangelicals, on the other hand, are not examined here as they less often engaged in such discourse. Across denominations, they were imbued with what Markku Ruotsila shows was a relatively consistent "anti-internationalism". ${ }^{16}$ The rising influence of premillennial dispensationalist teaching among fundamentalist churchesa belief that contemporary history as interpreted through biblical prophecy revealed the activity of the Antichrist and the end of the world-lent itself to a fear of international conspiracy that did not sit naturally with the kind of internationalism examined here. ${ }^{17}$ This essay uses "Christian internationalism",

15 E. B. Sweeney, "Nationalism and Internationalism through the Churches: The Catholic Church and the Promotion of Peace Attitudes", Journal of Educational Sociology, 10/6 (Feb. 1937), 338-42, 341-2. Dan McKanan, Prophetic Encounters: Religion and the American Radical Tradition (Boston, MA, 2011).

16 Markku Ruotsila, The Origins of Christian Anti-internationalism: Conservative Evangelicals and the League of Nations (Washington, DC, 2008).

17 As well as Ruotsila, see the early chapters of Timothy P. Weber, On the Road to Armageddon: How Evangelicals Became Israel's Best Friend (Grand Rapids, MI, 2004) for a survey of early twentieth-century dispensationalist interpretations of world affairs. There are important exceptions to be noted, such as W. Cameron Townsend's friendship with Mexican president 
then, to refer to the substantive impulse of these particular subjects-using their language, and that of scholars since-rather than their demographic or denominational inclusivity. ${ }^{18}$

Awareness of the limited demographic and social base of the movement actually serves to bring its significance into sharper relief, however. In recent years, historians such as David Hollinger, Elesha Coffman and David Sehat - to name a few-have turned fresh attention to the "establishment" and "mainline" status of ecumenical Protestant leaders in the early to mid-twentieth century. ${ }^{19}$ As Hollinger memorably suggested, "If you were in charge of something big before 1960, chances are you grew up in a white Protestant milieu." ${ }^{20}$ As Sehat has noted, despite the formal legal structure of disestablishment and religious freedom, Protestants have historically been at the center of a "moral establishment". ${ }^{21}$ Sherwood Eddy and his colleagues need to be seen as addressing two audiences in the US. While they spoke of wanting to shape "public opinion" at large, they arguably had their greatest impact as agents of Protestant self-criticism-as relatively radical Protestants speaking to other Protestants about world politics. But precisely because of the establishment status of those they addressed, there is good reason to see their longer-term impact as pervasive and widespread.

Cardenas and opposition to US oil interests. William L. Svelmoe, "The Gringo and the General: W. Cameron Townsend as Lázaro Cárdenas's 'Man in America," in Daniel H. Bays and Grant Wacker, eds., The Foreign Missionary Enterprise at Home: Explorations in North American Cultural History (Tuscaloosa, AL, 2003), 171-86.

18 For examples of the use of the term in the interwar period see William Pierson Merrill, Christian Internationalism (New York, 1919). Sidney L. Gulick, "The Foreign Policies of the United States and the Success of Foreign Missions", in Committee on the War and the Religious Outlook (Federal Council of Churches of Christ in America), ed., The Missionary Outlook in the Light of the War (New York, 1920), 280-91, 288. See also the "Message" of the Universal Christian Conference on Life and Work, Stockholm 1925, reprinted in Michael Kinnamon and Brian E. Cope, eds., The Ecumenical Movement: An Anthology of Key Texts and Voices (Geneva: WCC Publications, 1997), 265-7. For its use in recent scholarship see Jun Xing, "Christian Internationalism in the Crucible: 1931-1935", chap. 5 of Xing, Baptized in the Fire of Revolution: The American Social Gospel and the YMCA in China, 1919-1937 (Bethlehem, PA, 1996), 125-51; and Heather A. Warren, Theologians of a New World Order: Reinhold Niebuhr and the Christian Realists (New York, 1997), 71.

19 David A. Hollinger, After Cloven Tongues of Fire: Protestant Liberalism in Modern American History (Princeton, NJ, 2013). David Sehat, The Myth of American Religious Freedom (Oxford, 2011). Elesha J. Coffman, The Christian Century and the Rise of the Protestant Mainline (New York, 2013). William Hutchison's earlier discussion of the Protestant establishment is indispensable. William R. Hutchison, Between the Times: The Travail of the Protestant Establishment in America, 1900-1960 (Cambridge, 1989).

$20 \quad$ Hollinger, "After Cloven Tongues of Fire", 23.

21 Sehat, The Myth of American Religious Freedom, 5. 


\section{SETTING THE SCENE: EDDY'S TRAVELING SEMINAR}

The best place to start in tracing Eddy's transfer of his missionary vocation into his new Christian internationalism is at the founding of his iconic "Traveling Seminar". Founded after World War I, Eddy's annual steamship tours were arguably his most distinctive and important contribution to the movement he helped to build. The "American Seminar", as it was alternatively known, was an annual study tour of Europe, with a particular focus on Britain and Germany. ${ }^{22}$ It was a translation of missionary mobility into internationalism: a replication of the same loop between travel, networking and knowledge of international affairs that Eddy had long practised as a missionary world traveller. ${ }^{23}$ But by giving Americans exposure to world conditions through travel, the seminar was intended as an exercise in international relations, an effort, in the language of the day to create "an international mind". Certainly, participants saw its significance in such terms. Having freshly returned from Eddy's 1927 tour, F. Ernest Johnson, director of the Department of Research and Education in the US Federal Council of Churches, claimed, "No other single factor has been more potent in securing recognition in America of an international viewpoint." ${ }^{24}$ The Christian Century, a key liberal Protestant magazine whose editor, Charles Clayton Morrison, was also an Eddy seminar participant, wondered at the "enormous significance of ... American minds of many types who return to their homes bearing the inspiration of new international understanding".

Eddy himself cast the seminar as a possible "avenue to international understanding and peace". ${ }^{25}$ An advertisement for the seminar made clear the intended instrumentality of the practice:

The party will be restricted to persons in public life who will actively promote better international relations upon their return, and who through editorial responsibility, public speaking or writing, will be able to exert wide influence on American public opinion. It is requested that others do not apply for membership. ${ }^{26}$

22 For Eddy's account of the seminar see Sherwood Eddy, A Pilgrimage of Ideas: Or the Re-education of Sherwood Eddy (New York, 1934), 183-99; and Eddy, Eighty Adventurous Years: An Autobiography (New York, 1955), 128-51. See also Nutt, The Whole Gospel for the Whole World, 201-17.

23 Daniel H. Bays and Grant Wacker, "Introduction: the Many Faces of the Missionary Enterprise at Home", in Bays and Wacker, The Foreign Missionary Enterprise at Home, 1-9, 2.

24 F. Ernest Johnson, untitled manuscript, in Eddy Papers, Box 21, 6.

25 Eddy, Eighty Adventurous Years, 128.

26 "An Announcement: Study Pilgrimage to Europe", The World Tomorrow, Jan. 1927, 39. 
Perhaps because of its selective enrolment policy, the seminar did exert a notable ripple effect in American public life. A “who's who” of Progressive leaders and thinkers were influenced by their time on Eddy's steamship. The first tour in 1921 began with less than a dozen participants. By 1926 the tour consisted of 140 people. By 1927 the cumulative total of alumni was nearly a thousand. ${ }^{27}$ Hubert Herring, head of the Committee on Cultural Relations with Latin America, was inspired to start his own "Latin American Seminar" after his experience of Eddy's seminar. ${ }^{28}$ Ben M. Cherrington, YMCA international-relations teacher, and later the first head of the US State Department's Culture Division, was also an early seminar traveller. ${ }^{29}$ And it was on a trip through the Ruhr with the Eddy seminar in 1923 that Reinhold Niebuhr turned to pacifism, confessing in his journal that he was finally "done with the war business", a position he would famously modify (bringing Eddy with him) by the end of the next decade. ${ }^{30}$

The tour's occasional journeys into Russia were significant in their own right. They gave Eddy the material from which to write The Challenge of Russia, in which he made his plea for a third-way synthesis of capitalist and Marxist social orders. And they led him to support US recognition of the Soviet Union in the late 1920s. Indeed, Eddy's travelling seminar-in the collective capacity of the seminar-submitted to President Coolidge arguments in favor of US recognition of Russia. ${ }^{31}$ Such rapprochement was not without controversy back home. Despite defending Christianity to Russians (Eddy and his party reportedly debated the merits of religion with several Russian atheists in a meeting sponsored by the Russian Ministry for Cultural Relations), the hostile Chicago Tribune focused in on critical comments Eddy made in Russia about "nations ruled by swollen, selfish capitalism". Such coverage only added to the growing calls for his resignation from the YMCA. ${ }^{32}$ Significantly, though, the seminar gave experience of Russia to a generation of Christian leadership. For some, such as Methodist minister and theologian Harry F. Ward, this correlated with an adoption of popular-front

27 “A Traveling Seminar”, Christian Century, 23 Sept. 1926, 1159.

28 See Eddy, Pilgrimage of Ideas, 184. "Seminars below the Rio Grande", World Tomorrow, 19 April 1933, 384.

29 Ben Cherrington's name is in the guestbook for 1921, held in Box 23, Eddy Papers. On Cherrington see "Culture Division", Time, 8 Aug. 1938, www.time.com/time/magazine/article/ 0,9171,931422,0o.html, accessed 27 June 2013.

30 Later published in Reinhold Niebuhr, Leaves from the Notebook of a Tamed Cynic (Cleveland, OH, 1964; first published 1929), 67-8.

31 See "For Russian Recognition", The World Tomorrow, October 1926, 180.

32 "Eddy Talk in Russia Causes Chicago Protest", Chicago Daily Tribune, 17 Aug. 1926, 10. Sherwood Eddy, "Russia Revisited: A Reply to Statements Appearing in The Chicago Tribune", Association Men, Oct. 1926, 61, 74, copy held in Eddy Papers, Box 6, Folder 112. 
communism in the 1930s; for others such as Reinhold Niebuhr, and Eddy himself, the experience provided a resource for later anticommunist critique.

The Traveling Seminar was one part-the most iconic part-of a larger vocational transfer whereby Eddy, like other missionaries, drew on his missionary background to give leadership to the emerging Christian internationalist movement. As a semi-formal institution in which a network of leading liberal Protestant thinkers developed their views on world affairs, the importance of his seminar is unmistakable. And its significance is even greater when seen against the backdrop of the 1920s, a period in which prevailing political winds encouraged people to ignore international affairs in the spirit of returning to "normalcy" and putting "America First".

But the question at hand is, how did Eddy, the missionary to India from the "high imperial era", become a leader of this Christian internationalism in the 1920s? Three factors need to be taken into account: Eddy's liberal evangelical faith and theology, his uptake of a Rauschenbuschean social ethics after World War I, and his place in the missiological crisis of the 1920s. Of the three, though, it was the final one-the changes in missionary attitudes and ideas-that gave Eddy's internationalism its shape.

\section{EDDY THE LIBERAL EVANGELICAL}

Eddy's internationalist politics were not simply the fruit of a drift toward theological modernism away from evangelical roots. For Eddy, it was a case of both, of one being bolted onto the other, even sometimes at the expense of logical consistency. Thus the phrase that best characterizes Eddy's theology is "liberal evangelical" - for he was distinctively both liberal and evangelical his whole career. Most of the central emphases of the evangelical belief and piety that Eddy developed in the 1890 os he maintained throughout the interwar period and apparently until his death in 1963. Even in the 1920 s as his politics went leftward he still announced his ongoing belief in certain great "essentials" that he believed provided a middle ground between the poles of fundamentalism and modernism. ${ }^{33}$ He confessed he did "believe in the inspired Word of God"; he did "believe in the incarnation of God in Jesus Christ" and see Christ as the "risen divine Savior". He believed in Christ's "vicarious atonement", and, quoting Acts 4:12, pledged, "there is no other name under Heaven whereby we may be saved". Yet, at the same time, he wrote of abhorring Reformed theologian B. B. Warfield's

Eddy, "What Are the Great Essentials?", undated manuscript (c.1924), Eddy Papers, Box 6, Folder 135. The manuscript related closely to Eddy and William Horace Day, The Modernist-Fundamentalist Controversy, Christianity and Personal Problems Series, No 2 (Garden City, NY, 1924). See Nutt, The Whole Gospel for the Whole World, 178-9. 
teachings on damnation and predestination, and saw Gandhi's spirituality as close-if not one with-the Christian experience. ${ }^{34} \mathrm{He}$ avoided discussion of sin and careful soteriology. Instead, as an apologist, he sought to synthesize the insights of modern science, sociology and psychology with his evangelicalism, arguing, for example, that evolution was not necessarily "materialistic ... or self-sufficient", and that the psychological insights of William James were but another reason to pray and surrender to Christ. ${ }^{35}$

The two most notable evangelical emphases in Eddy's theology were his conversionism and his commitment to cultivating and promoting practices of intense devotional piety. Both were established in the revivalist heyday of D. L. Moody's collegiate campaigns. It was after listening to Moody, while as a student attending one of the famous Northfield conferences of the 189os, that Eddy recalled, "God became real to me and religion vital." ${ }^{6}$ Importantly, he showed no signs of disavowing his revivalist heritage past even in the 1930s-his most politically radical years, when, for example, he was a member of the Socialist Party. ${ }^{37}$ Thus, as Eddy moved from missionary to internationalist, he sought to combine preaching about the social sins of American racism and imperialism with traditional evangelistic preaching to students-seeking their conversion to Christ, enrolling them in Bible study fellowships and encouraging them to spend time in devotional prayer and Bible reading. A renowned preacher and orator, Eddy often wove together the florid preaching style and emotional register of his evangelism with his internationalist political arguments. In a publicized address to the SVM in 1920, he addressed the political urgency of the League of Nations question- "America was on trial" before the bar of world opinionbut concluded the address in conversionist terms well familiar to evangelical Protestants: "One thing I know. Jesus Christ saves and satisfies. Jesus Christ can give you this new life. Will you take it? Will you get right with God?"38

Although Eddy had a brief foray into theological study at Union Theological Seminary and Princeton Theological Seminary (two very different places to study in the 1890s), it was his training, immersion and eventual leadership in

34 On Warfield see Eddy, Pilgrimage, 38; on Gandhi see ibid., 72.

35 Sherwood Eddy, Facing the Crisis: A Study in Present Day Social and Religious Problems (New York, 1922), 111-12, 128, 222.

36 Eddy, Eighty Adventurous Years, 117-18.

37 See for example, Eddy, Pilgrimage, $53 \mathrm{ff}$.

38 Sherwood Eddy, "Gospel Indispensable to the Students of North America", in Burton St John, ed., North American Students and World Advance: Addresses Delivered at the Eighth International Convention of the Student Volunteer Movement for Foreign Missions, Des Moines, Iowa, December 31, 1919, to January 4, 1920 (New York, 1920), 191-6, 196. Compare newspaper coverage of Eddy's League arguments in "World Revulsion against America", New York Times, 4 Jan. 1920, 3. 
the YMCA that were most influential in forming his liberal evangelicalism. At Union, Eddy was disillusioned by what he saw as incompetence among faculty members in the 1890 s (with the exception of church historian A. C. McGiffert) and he left before finishing in order to complete the qualification at Princeton. ${ }^{39}$ At Princeton, he was repelled by Warfield's dogmatics and absorbed little, if any, of the Presbyterianism on offer. ${ }^{40}$ By any measure it was the YMCA that served as Eddy's real training ground and the body that de facto ordained him. Eddy came to the fore of the YMCA in a period when a post-Civil War culture of strict evangelical orthodoxy, once maintained by the implementation of strict doctrinal "tests" for leaders, was giving way to a looser, consensus-oriented evangelicalism. ${ }^{41}$ That is, as the seeds of theological liberalism and modernism began to sprout in American seminaries and churches in the late nineteenth century, the YMCA, as a trans-denominational national body representing the evangelical mainstream, sought to maintain unity in its swelling ranks principally by avoiding difficult and controversial issues. ${ }^{42}$ Leaders felt that by insisting on what they saw as the central things-practices of evangelism and conversion to Christ, the promotion of Bible study, and the cultivation of an intense and experientially rich devotional piety-they could remain as a para-church body in which Protestants would stay together, and stay busy for Christ.

Eddy's liberal evangelicalism was an important and distinctive ingredient in his Christian internationalism. Reinhold Niebuhr reasoned that Eddy's combination of evangelical pietism and social concern was one of the most significant, and unusual, aspects of his legacy - an instructive example for others to follow in the mid-twentieth century. ${ }^{43}$ Robert Speer, writing earlier, was probably more accurate in identifying Moody-era revivalism as having a strong tradition of social concern alongside its emphasis on individual salvation and piety all along (an observation later affirmed by Smith in his study of revivalism and social reform). ${ }^{44}$ As a relatively constant feature of Eddy's work and thought, though, his liberal evangelicalism does not, on its own, explain the postwar change from missionary

39 On Union see Nutt, The Whole Gospel for the Whole World, 16. Eddy acknowledged change in this regard, claiming that by the 1930s Union had "the strongest theological faculty in the world". See Eddy, Pilgrimage, 37.

40 On Princeton see Eddy, Pilgrimage, 38; and Nutt, The Whole Gospel for the Whole World, 28.

$41 \quad$ This analysis draws on C. Howard Hopkins's old but excellent account of Christianity in the YMCA, in his History of the YMCA in North America (New York, 1951).

42 Ibid., 375-380.

43 Reinhold Niebuhr, "Introduction", in Eddy, Eighty Adventurous Years, 9-12.

44 For Speer's observation see John F. Piper, Robert E. Speer: Prophet of the American Church (Louisville, KY, 2000), 325. Timothy L. Smith, Revivalism and Social Reform: American Protestantism on the Eve of the Civil War (Baltimore, 1980). 
to internationalist. His consensus-oriented mainline theology instead was like a modular furniture kit upon which an extraordinary variety of extensions could be bolted. And after World War I, one of the most important additions was the Rauschenbuschean Social Gospel.

\section{EDDY THE SOCIAL GOSPEL CONVERT}

The catalyst for Eddy's turn to the Social Gospel was a combination of the shock of World War I with the "the shock of the global", to adapt a term that diplomatic historians have used elsewhere. ${ }^{45}$ For Eddy, travel through Europe, Asia and the Middle East in the aftermath of the war-particularly during 1919gave him unprecedented exposure to interconnected currents of anti-colonial nationalism, struggles for racial equality and economic and class conflict. Eddy had already worked in India as a YMCA missionary from 1896 to 1911, and from 1911 had frequently toured revolutionary China with his YMCA mentor and superior, John Mott (whose own inroads into China had caused President Wilson to offer him the position of ambassador there in 1913)..$^{46}$ Eddy was no stranger to anti-colonial sentiment, and in the 1910s offered his sympathies and his vision of a modern, independent China (albeit schooled into its modernization by American tutelage). ${ }^{47}$ But as Erez Manela has effectively demonstrated, the "Wilsonian moment" of 1919 was an extraordinarily fraught period in which to be travelling the world: both the promise of and the disillusionment resulting from Wilsonian ideas were fanning unrest-particularly in Egypt, India, China and Korea, where major political convulsions broke out. ${ }^{48}$ With the access afforded by his status as itinerant YMCA evangelist, Eddy travelled these very countries and more, conducting student evangelistic campaigns, and in the process crystallizing his observations about world affairs and developing an extensive network of local

45 Niall Ferguson, ed., The Shock of the Global: The 1970s in Perspective (Cambridge, MA, 2010).

46 On Mott's offer from President Wilson see Basil Matthews, John R. Mott: World Citizen (New York, 1934), 436-8.

47 See, for example, Sherwood Eddy, The New Era in Asia (New York, 1913); and related newspaper coverage, such as "Amazing Renaissance Is Now Sweeping All Asia", New York Times, 23 Nov. 1913, SM14; and "China Awakening on Broad Scale", Chicago Daily Tribune, 12 Jan. 1914, 5. On the aspect of modernization under American tutelage see Varg, Missionaries, Chinese, and Diplomats, 76-7; and Davidann, A World of Crisis and Progress, 154-8. On simultaneously promoting Chinese nationalism and American cultural imperialism see Andrew Preston, Sword of the Spirit, Shield of Faith: Religion in American War and Diplomacy (New York, 2012), 195.

48 Erez Manela, The Wilsonian Moment: Self-Determination and the International Origins of Anticolonial Nationalism (Oxford, 2007). 
contacts that often encompassed political leadership at the highest level. ${ }^{49}$ These networks, gained through his YMCA work, were the same ones Eddy exploited in developing his Traveling Seminar itinerary for others. And Eddy's on-theground exposure to the global currents of anti-colonialism, anti-capitalism and racial unrest after the war helped crystallize his turn to the left politically and to the Social Gospel theologically.

Eddy's turn to the Social Gospel was signalled in a manuscript entitled "The Social Message: The Need of the Hour", which formed a basis for two of his important publications of the early 1920s_Everybody's World (1920) and Facing the Crisis (1922)..$^{50}$ In this manuscript-cum-working paper, Eddy made clear that the setting for his change of thinking was his travel through countries such as Japan, China, India, Ireland, Turkey and Egypt and his seeing "every country ... in the midst of some great national crisis". If this was the nature of the so-called peace, Eddy reasoned, then it was better to conclude that the war had not stopped at all; it had merely exposed deeper, more perennial social conflicts. "The world is still at war on three great battle-fronts of national, racial, and class-strife", he concluded. ${ }^{51}$ In the paper, Eddy also revealed his adoption of certain key elements of Social Gospel theology. Most obvious was his turn to the historical Jesus as an exemplar of ethical principles: an interpretation that he, by necessity, had to add to his existing evangelical belief in Christ as risen divine saviour. The substance of the paper consisted in Eddy rereading the New Testament gospels with the aim of "restudy[ing] the social principles of Jesus Christ".52 He distilled and filtered through parables and discursive passages such as the Sermon on the Mount in an attempt to discern bedrock ideas that could be applied to human group relations, abstracted from confessional particularity. His result was to present three great principles:

The principle of PERSONALITY, or the individual worth of each individual human life; the principle of BROTHERHOOD, or social solidarity, in the corporate relationship of the social organism and of the human life, mutually dependent upon each other in their common life; and the principle of SERVICE, as the motive and expression of life. ${ }^{53}$

49 Examples included Syngman Rhee of Korea, Premier Kato of Japan, President Chiang Kaishek of China, President Thomas Masaryk of Czechoslovakia, Prime Ministers Ramsay McDonald and David Lloyd George in Britain, Georg Michaelis (politician, and Chancellor for a brief term) in Germany.

50 Sherwood Eddy, “The Social Message, The Need of the Hour”, undated manuscript (c.1919), Eddy Papers, Box 6, Folder 133. See Eddy, Facing the Crisis, and Eddy, Everybody's World, British edn, ed. Basil A. Yeaxlee (London, 1920).

51 Eddy, "The Social Message, The Need of the Hour", 2.

52 Ibid., 4 .

53 Ibid., 5, capitalization in original. 
Although Eddy does not cite them (an unfortunate habit at times), the influence of two theologians whose works were circulated widely in American Social Gospel circles is readily apparent. Echoes of both the substance and form of German theologian Adolf von Harnack's writing is clear in Eddy's reading of Jesus as espousing three moral principles. Widely read in American seminaries, and later a regular speaker on the Eddy Traveling Seminar (and clearly a contact of Eddy's), Harnack famously reduced Christianity to three apparently essential currents in Christ's life and teaching: "Firstly, the kingdom of God and its coming. Secondly, God the Father and the infinite value of the human soul. Thirdly, the higher righteousness and the commandment of love." ${ }^{54}$

Closer to home, the influence of New York's most famous Social Gospel preacher and author, Walter Rauschenbusch, was also clear. Eddy's discussion of "brotherhood" as "social solidarity, in the corporate relationship of the social organism", could have been lifted from any of Walter Rauschenbusch's Christian socialist analyses of the need for economic democracy. ${ }^{55}$ Indeed, later he recalled that it was "due partly to that true prophet, Walter Rauschenbusch", that he began after the war to "realize the social implications of religion". ${ }^{6}$ While Eddy never developed an elaborate theology of the immanence of the "Kingdom of God" in social relations as Rauschenbusch did, he firmly retained the latter's stress on social and structural sin. ${ }^{57}$

Eddy's conversion to Social Gospel theology, while personally profound, was not unique to him. As Ian Tyrrell persuasively argues, there can be traced a wider pattern whereby the "seeds of the social gospel" were sown in missionary experiences abroad in this period..$^{8}$ But it is not enough merely to note that Eddy joined an older stream of Social Gospel thinking in his conversion to a social message in 1919. There was, after all, no necessary flow from the liberal Social Gospel theology of the 1900s to the anti-imperialist, anti-racist and anti-nationalist campaigns of Christian internationalists in the 1920s. The Social Gospel had been expressed in a variety of positions on American foreign relations. "It seems to me that God, with infinite wisdom and skill, is training the Anglo-Saxon race for an hour sure to come", wrote leading Social Gospel

54 Adolf von Harnack, What Is Christianity?, trans. T. Bailey Saunders (New York, 1908), 55.

55 See, for example, Walter Rauschenbusch, Christianity and the Social Crisis (New York, 1907); and Rauschenbusch , Christianizing the Social Order (New York, 1912). See Gary Dorrien's discussion of Rauschenbusch in Social Ethics in the Making: Interpreting an American Tradition (Chichester, 2009), 83-104.

56 Eddy, Pilgrimage, 65.

57 For Walter Rauschenbusch's treatment of sin as "solidaristic" see Rauschenbusch, A Theology for the Social Gospel (Nashville, 1978; first published 1917).

58 Ian R. Tyrrell, Reforming the World: The Creation of America's Moral Empire (Princeton, NJ, 2010), 182. 
minister Josiah Strong, relishing the possibility of further US expansion in the Western hemisphere. Anglo-Saxons had a "genius for colonizing", he enthused.59 For Washington Gladden, next to Rauschenbusch one of the Social Gospel's leading exponents, the Social Gospel had reinforced his vision of American exceptionalism. The foreign policies of Presidents McKinley, Roosevelt and Taft made them equivalent to "great missionaries of the cross." 60 And although near the end of his life Rauschenbusch applauded the Social Gospel being "translated into international terms", in his earlier work for his German Baptist denomination he had used his pen to advertise German theological education as part of an effort to ensure white people's upper hand "against the blacks of the South and the seething yellow flocks beyond the Pacific." ${ }^{11}$ Clearly the Social Gospel had not always implied opposition to the white peril.

Eddy's importance and that of his network consists in the way they adapted Social Gospel methodologies to the new politics of race, empire and nation in the 1920s. They did indeed take up the Social Gospel logic of seeing Christian ethics in structural terms — of seeking to "Christianize the social order", in Rauschenbusch's phrase-but they brought to such logic new norms, sensibilities and substantive commitments that were not derived from the Social Gospel itself. Contrary to the Anglo-Saxonism of Strong, Gladden and Rauschenbusch, for Eddy, applying "the principles of Jesus" would mean "the recognition of the infinite worth of every man before God, whether white or black, brown or yellow". ${ }^{62}$ The Social Gospel method of structural ethics was the medium, antiimperialism and racial equalitarianism the content. To find the source of such content a better place to look than the Social Gospel is the missionary enterprise of which Eddy was a part.

\section{EDDY AND THE MISSIOLOGICAL CRISIS OF THE $1920 \mathrm{~S}$}

Eddy's internationalism was profoundly shaped by his proximity to the missiological crisis of the 1920s. Such a crisis-as has been well documented by historians of missions from Charles Forman to William Hutchison and Grant Wacker-consisted in an unprecedented groundswell of criticism of the

59 Josiah Strong, Our Country: Its Possible Future and Present Crisis (New York, 1885), 174, 173 .

60 Washington Gladden, The Nation and the Kingdom, repr. in Robert T. Handy, ed., The Social Gospel in America, 1870-1920: Gladden, Ely, Rauschenbusch (New York, 1966), 145-6.

${ }_{61}$ Rauschenbusch, A Theology for the Social Gospel, 4. "Seething yellow flocks" from a fundraising letter for the German Department at Rochester Seminary cited in Dorrien, Social Ethics, 93.

62 Eddy, Facing the Crisis, 169. 
missionary enterprise so that its very validity came into question as never before in the era of modern missions. ${ }^{63}$ As Hutchison showed, many critics were liberal modernists for whom the traditional evangelical claims of salvation through Christ - and hence a theological basis for traditional missions-were no longer tenable. John D. Rockefeller Jr, and the famous “Laymen's Inquiry" he funded under the leadership of William Ernest Hocking, represented the liberal modernist critique. ${ }^{64}$ So too did Pearl Buck, novelist and daughter of missionaries in China. As Grant Wacker has shown, Buck exemplified a widespread revulsion not only to the missionary enterprise of the pre-war period-nor merely to the association between missions and political imperialism-but also to the cultural and spiritual "imperialism" inherent in preaching an exclusivist gospel that called people to leave other religions in favour of Christ. ${ }^{65}$ Meanwhile, at the other end of the spectrum, the missionary enterprise came under fire from conservative fundamentalist leaders who believed that missionary boards had been so corrupted by liberalism that they were now useless for missions traditionally understood-J. Gresham Machen's voice was among the most articulate of this camp. ${ }^{66}$

In between these polar positions-seeking to refashion a middle-ground consensus - were several of the major leaders of the YMCA and SVM, such as John R. Mott, Robert E. Speer (who represented Presbyterian missions as well as the SVM) and Sherwood Eddy. Many of these leaders and many others in mainline seminaries and in ecumenical forums such as the International Missionary Committee were, like Eddy, liberal evangelicals rather than modernists (Speer and Mott were more conservative in theology than Eddy) and correspondingly sought to salvage the kerygmatic aspects of the traditional missionary enterprise rather than discard them entirely. They insisted on the perennial validity of missions, but argued that only in a reconstituted mode, whereby the gospel was shorn of its association with Western imperialism, was the enterprise viable. This left them in the position of decrying political imperialism while still, in Speer's

63 Forman, "A History of Foreign Mission Theory in America". William R. Hutchison, Errand to the World: American Protestant Thought and Foreign Missions (Chicago, 1987). Grant Wacker, "Second Thoughts on the Great Commission: Liberal Protestants and Foreign Missions, 1890-1940", in Joel A. Carpenter and Wilbert R. Shenk, eds., Earthen Vessels: American Evangelicals and Foreign Missions, 1880-1980 (Grand Rapids, MI, 1990), 281-300.

64 William E. Hocking, ed., Re-thinking Missions: A Laymen's Inquiry after One Hundred Years (New York, 1932). On Rockefeller and Hocking see Hutchison, Errand, 148-9, 158-64.

65 Wacker, "Pearl S. Buck and the Waning of the Missionary Impulse".

66 On Machen's criticisms see Hutchison, Errand, 173-5. 
words, retaining the "fine spiritual imperialism" of the gospel of salvation in Christ. $^{67}$

This middle-ground response-of defending missions while seeking to reconstitute them-was where most of the intellectual energy came from that animated Christian internationalism in the 1920s. As these missionary leaders sought to reconstruct missions on a new footing, they were compelled to engage with the efforts and demands of those in non-Western, missionary-"receiving" countries to obtain independence from relations of Western tutelage and to establish equality and mutuality. As Forman notes, in the interwar period missionary theorists responded with "a new appreciation for the culture of the East and an emphasis on emerging churches in Asia and Africa"; they sought to foster a new ethos which he characterizes as "ecumenical sharing"an emphasis on "the need for churches around the world to help each other understand the Christian faith". As the process of "indigenization" occurred, they hoped, each national and cultural grouping would contribute its particular strengths and emphases to the common good of the ecumenical, supra-national Church. ${ }^{68}$ The emerging ecumenical ethos formed an important conceptual base for Eddy's political internationalism. Ecumenism and internationalism both meant cultivating awareness of the wider solidarity of mankind over narrow national loyalties. And along with the stress on ecumenical solidarity came two closely related ideas, vital to the character of interwar Christian internationalism. One was that racial equality was an essential but lost Christian truth that needed to be recovered in the face of rising scientific and political racism. The other was that precisely because of failures in areas such as race relations and international relations, the locus of Christianity could no longer be seen as the West. America, and other Western nations, could not claim to be "Christian nations" in a sea of non-Christian nations; the term simply had no validity.

In the 1920 an outpouring of books, lectures and addresses from missionary leaders made the forceful case that notions of white supremacy, whatever their apparent grounding in science and anthropology, were not consonant with true, apostolic Christianity. Not only were such views sub-Christian, they argued; they were also in themselves a singular cause of global unrest and injustice. The New Testament idea of trans-ethnic solidarity in the body of Christ needed to be recovered and applied to present-day race relations at large, they argued, frequently citing or alluding to Pauline passages like Ephesians 2:14 ("for he is our peace, who hath made both one") or Galatians 3:28 ("There is neither Jew

\footnotetext{
67 Hutchison rightly points out that the most important debates occurred between the liberal Hocking end of the spectrum and the middle ground of Speer. Hutchison, Errand, 175. Robert E. Speer, The Finality of Jesus Christ (New York, 1933), 372.

Forman, "A History of Foreign Mission Theory in America", 98.
} 
nor Greek, there is neither bond nor free, there is neither male nor female: for ye are all one in Christ Jesus"). ${ }^{69}$ Eddy's closest missionary colleague, John R. Mott, presented these ideas on an extraordinary trip to Australia in 1926, which was then subject to the "white Australia" immigration policy. To a community fashioning itself, in conscious unity with the United States at the time, as a "white man's country" in the Asia Pacific, Mott urged Australian Christians to "wage uncompromising warfare against ... all unjust or unequal racial arrangements, laws and practices", including its exclusionary immigration practices. $^{70}$ He appealed neither to biological nor to social science, but to all the Christocentric evangelical tenets he could muster: "By His Incarnation, by the all-inclusiveness, or comprehension of His gospel and Kingdom, by His breaking down the middle wall of partition on the Cross ... He reveals Himself as the One through whom the unity of the human race is discovered and realized." 71

Mott's approach was mirrored and elaborated more systematically by others, including his British counterpart and fellow leader of the International Missionary Committee, Joseph $\mathrm{H}$. Oldham. Having addressed the critical importance of race relations to international relations in his The World and the Gospel (1916), Oldham used his Christianity and the Race Problem (1924) to survey contemporary scientific literature on race and juxtapose it with Christian theology. ${ }^{72}$ Although, as Mark Edwards notes, Oldham cited Boasian anthropology approvingly, his emphasis was on arguing that biblical personalism (citing Ernst Troeltsch) generated theological truths of equality that stood over and against contemporary scientific discourses of racial inequality. ${ }^{73}$ Meanwhile, in the US, Mott and Eddy's old SVM colleague, Robert Speer, president of the Federal Council of Churches after 1920, convened a special Commission on the Church and Race Relations. With that body's and the Missionary Education Movement's support, and with input from around the world, Speer published a

69 All quotations here are from the King James Version.

$70 \quad$ John R. Mott, “The Race Problem: Address Given to the Australian Missionary Conference, Melbourne, April 12, 1926", in Addresses and Papers of John R. Mott, vol. 5, The International Missionary Council (New York, NY, 1946), 608-20, 619. On the US and Australia fashioning themselves as "white man's countries” in the 1920 s see Marilyn Lake and Henry Reynolds, Drawing the Global Colour Line: White Men's Countries and the International Challenge of Racial Equality (Cambridge, 2008).

71 Mott, "The Race Problem”, 620.

72 Joseph H. Oldham, The World and the Gospel (London, 1916); and Oldham , Christianity and the Race Problem (London, 1924).

73 Oldham, Christianity and the Race Problem, 20. For Mark Edwards's observation on Boasian anthropology see Mark Edwards, “'God Has Chosen Us': Re-Membering Christian Realism, Rescuing Christendom, and the Contest of Responsibilities during the Cold War”, Diplomatic History, 33 (2009), 67-94. 
book entitled Of One Blood (an allusion to Paul's speech in Acts 17:26) which he hoped would "bring the white world short up against the folly of the proposition laid down by Lothrop Stoddard". ${ }^{4}$

But it was not simply a case of missionaries encountering and looking at diversity; they voiced their views on race in partnership with non-white leaders in emerging ecumenical organizations. The missionary and ecumenical organizations connected to Mott in particular provided vital spaces for non-white Christian leaders from Asia, Africa and the United States to give voice to protests about existing race relations and to assert their demands for recognition of racial equality on an international stage. For example, at the 1922 Peking conference of the World's Student Christian Federation (an ecumenical organization essentially founded by Mott and closely connected to the YMCA) a special study section on Christianity and International and Inter-racial Problems dominated by Japanese students produced a text known as the "Peking Resolutions", announcing their belief "in the fundamental equality of all the races and nations of mankind" and insisting it was their "Christian vocation to express this reality in all our relationships". ${ }^{75}$ Another example was the landmark 1928 world conference of the International Missionary Committee in Jerusalem, which featured a study section on race relations headed by black YMCA luminary Max Yergan and others such as John Hope, president of Morehouse College, Atlanta. Through their reports and recommendations, which were stridently anti-imperialist in their analysis, the section steered the International Missionary Committee to officially resolve that "any discrimination against human beings on the ground of race or color" was a "denial of the teaching of Jesus". ${ }^{6}$

Immersed in this missionary-ecumenical world, Eddy too gave priority to race in his analyses of world politics. In a typical mid-1920s analysis of the "Present World Situation", for example, what worried Eddy more than the fate of the League of Nations was the level of global racial conflict and tension. Many Japanese people he knew were deeply offended by America's recent exclusionary immigration

74 Robert E. Speer, Of One Blood: A Short Study of the Race Problem (New York, 1924). On Lothrop Stoddard see Piper, Robert E. Speer, 339.

75 Cited in Philip Potter and Thomas Wieser, Seeking and Serving the Truth: The First Hundred Years of the World Student Christian Federation (Geneva, 1997), 70. On Japanese influence see Parker, The Kingdom of Character, 157. By way of contrast, on the rejection of a Japanese-authored racial equality clause in the treaty deliberations at Versailles, doubtless known to delegates at Peking, see N. K. A. Meaney, History of Australian Defence and Foreign Policy 1901-23, vol. 2, Australia and World Crisis, 1914-1923 (Sydney, 2009), 376-8.

76 "Statement Adopted by the Council: Racial Relationships", International Missionary Council, Report of the Jerusalem Meeting of the International Missionary Council, March 24th-April 8th, 1928, vol. 4, The Christian Mission in the Light of Race Conflict (London, 1928), 237-45, 237, 238. 
laws. Eddy recalled a conversation with "a leading Japanese statesman in Geneva" (likely to have been Nitobe Inazō, a YMCA figure later connected to the League of Nations ${ }^{77}$ ), who said the legislation was more "morally devastating" than the recent great earthquake. Regarding China, Eddy supported Chinese calls for the end of unequal treaties and the racial exclusion zones they enshrined. He applauded Gandhi's protest against British colonialism (and later spent an evening with Gandhi at his ashram). ${ }^{78}$ Then there was America: "In no country more than our own is there need of facing the unresolved race problem and of asking whether Christian principles ... are to be supreme."79

Closely related to criticisms of America and other imperial powers' record on race relations were deep questions over the legitimacy of calling America and other Western missionary-sending nations "Christian nations". The term, and the imperialistic relationship it helped sustain, was no longer tenable, according to missionary leaders seeking to reconstitute the enterprise. Mainline Protestant missionaries from the 1890 os to the 1910 s had argued confidently that Christianity needed to be adopted by countries such as China and Japan in order to ensure that their modernization processes were successful and ethical in character; the implication was that America could export a model to be applied globally. ${ }^{80}$ Christian "principles" were the key to building a happy and just social order. By the 1920 s this narrative, if not in tatters, was widely viewed with deep scepticism; instead, many missionaries and those with whom they were in contact argued that Christian nations had not demonstrated the superiority of their own social and political orders. They had failed to meet their own Christian ethical standards in inter-group relations, as seen in the mass killing of the Great War, in the race for imperialistic expansion or in ongoing racial injustice. Either the premise of the original equation between Christianity and a right social order was not true, or Christian countries simply had not tried hard enough to implement it. Missionary internationalists such as Eddy chose to stress the latter. On one level, then, their questioning of the term "Christian nation" functioned as a jeremiad: America needed to repent and do better at being Christian in order to recover its true identity. But at the same time, their rejection of the phrase served

77 For background on Nitobe see Akira Iriye, Cultural Internationalism and World Order (Baltimore and London, 1997), 44-5.

78 On the ashram see Eddy, Pilgrimage, 106-7.

79 All quotations above from Eddy, "The Present World Situation" (1925), unpublished manuscript, Box 6, Folder 110, Eddy Papers, 4-5. Manuscripts such as this and the "Social Message" discussed above functioned as working papers and central repositories of material for Eddy's myriad publishing; they thus provide a useful gauge of themes circulating more broadly in his work.

8o This was the implication of Eddy, The New Era in Asia, for example. See also Forman, "A History of Foreign Mission Theory in America", 97. 
to express the new internationalist, ecumenical consciousness that missionaries sought to cultivate; it was the negative voicing of their positive argument for wider solidarities.

The crisis surrounding the Christian-nation idea made its presence felt across bodies such as the SVM, YMCA and IMC - the same cluster of organizations and networks in which ideas of racial equality were coming to the fore. Many sought changes to terminology that would frame America as one mission field among others. During the 1920 s the SVM renamed "foreign missions" as "world missions" and changed the language of their "pledge card", used for recruiting missionaries, from "foreign missionary" to "Christian witness abroad" ${ }^{81}$ At missionary conventions at home and abroad it became axiomatic to refer to the notion of a Christian nation with self-consciousness and embarrassment. The phenomenon brought with it new speech rules: qualifiers, quote marks and linguistic distancing devices. Presiding at the Jerusalem 1928 conference, for example, Mott distanced himself from his earlier language of a "Christian west", with the insertion of a telling set of qualifiers: he referred instead to "our socalled western Christian civilization" and "the so-called non-Christian world". ${ }^{2}$ A major preparatory paper used for discussion at Jerusalem, prepared by the prominent American Quaker theologian Rufus Jones (a colleague of Eddy's in the Fellowship for a Christian Social Order), was more direct: "We go to Jerusalem, then, not as members of a Christian nation to convert other nations which are not Christian, but as Christians within a nation far too largely non-Christian." ${ }^{3}$ Leading liberal missions theorist Daniel Johnson Fleming, in his classic 1925 work Whither Bound in Missions, challenged the traditional cartography of missions, both literal and metaphorical:

It has long been the custom, when making missionary maps, to paint the sending countries white and the receiving countries black. In recent years, however, we have been startled into the realization that the West is part of the non-Christian world, and that there is no sharp division into lands that are white and those that are black unless, indeed, the West is of a deeper black because it has had access to Christ so long. ${ }^{84}$

81 Parker, The Kingdom of Character, 162. Valentin H. Rabe, The Home Base of American China Missions, 1880-1920 (Cambridge, MA, 1978), 177.

82 John R. Mott, "Expectations", address delivered at the Meeting of the International Missionary Council, in Report of the Meeting of the International Missionary Council at Jerusalem, March 24th-April 8th, 1928, vol. 8, Addresses and Other Records, (London, 1928), 25.

83 Cited in Speer, The Finality of Jesus Christ, 315.

84 Daniel Johnson Fleming, Whither Bound in Missions (New York, 1925), 47. On Fleming's missionary internationalism see Dana Robert, "The First Globalization: The Internationalization of the Protestant Missionary Movement between the World Wars", International Bulletin of Missionary Research, 26 (2002), 50-66. 
The old "moral mapping" of the missionary enterprise, to use Miroslav Volf's term, had lost its coherence. ${ }^{85}$

Sherwood Eddy echoed almost all of Fleming's argument in a reflection on his own lifetime's experience in The World Tomorrow in 1928. Yes, the missionary enterprise was still valid, he argued. But, satirizing his earlier self, he decried the attitudes with which it was once undertaken:

Then we felt a divine call to go from our own favored "Christian" nation to the backward "heathen" nations lost in darkness. Then, under the obligation of noblesse oblige, we felt called to take up "the white man's burden" and go out from our "superior" race to the backward peoples of the world ... we felt that we had everything to give and nothing to learn. We were often unconsciously complacent, paternalistic, imperialistic. ${ }^{86}$

Now, he argued, Christians would more appropriately adopt a posture of being "deeply disturbed" by the "semi-pagan order at home". How could Americans claim to be of a "superior" race when "we still lead the world in our record of lynching, in race and color prejudices"? How could Anglo-Saxon democracies claim to be superior when their imperialism "has conquered or exploited over half of Asia and all but one-thirtieth of Africa", and when together they spend more on naval armaments than the rest of the world combined? ${ }^{87}$

\section{EDDY THE ORGANIZER}

The nature of Eddy's intellectual trajectory would still be of interest had he not been so active and influential as an organizer. But if Eddy was typical of wider trends in liberal evangelical missionary self-criticism in the 1920s, he was also unique in his capacity to take those impulses and give them organizational expression in American public life. He did so in large part by providing organizational leadership - the greatest example being his annual steamship Traveling Seminar. But alongside the steamship tours, Eddy threw himself into the Protestant left's world of politically oriented associations and leagues after the war. He was active in the Fellowship of Reconciliation, John Dewey's League for Independent Political Action, Niebuhr's Fellowship of Socialist Christians, the Committee on Militarism in Education and many more. In addition he started, with Kirby Page, a new "Fellowship", the Fellowship for a Christian Social Order (FCSO). The latter brought mainline seminary faculty and presidents, senior Federal Council of Churches leaders, and missionaries together with radical

85 Miroslav Volf, Exclusion and Embrace: A Theological Exploration of Identity, Otherness, and Reconciliation (Nashville, 1996), 29.

86 Sherwood Eddy, "Why Missions?" The World Tomorrow, Jan. 1928, 18-20, 18.

87 Ibid., 18. 
Social Gospel activists and pacifists, and offered the sociality of small cell-group meetings and retreats for "mutual counsel, inspiration and cooperation". ${ }^{88}$

Perhaps most important, though, was the way Eddy used his money. Eddy's wealth, inherited from his father's considerable railroad interests, enabled him to foster a network of writers and speakers all of his own-a troop of younger, talented voices who benefited from world travel on his tours, who enjoyed proximity to some of the heights of Protestant power, and who, with Eddy's financial support, were enabled to write and publish independently. Elesha Coffman has demonstrated the way the need to establish financial stability influenced the Christian Century's positioning of itself as "mainline" in the period. ${ }^{89}$ Many other radical voices on the left had to beg for grants from the radically pro-labour American Fund for Public Service (known as the "Garland Fund" after its philanthropic founder), run by senior American Civil Liberties Union (ACLU) figures. ${ }^{90}$ Meanwhile, Sherwood Eddy was able to live off the interest generated by his inherited capital and still have enough left over to float a myriad of fledgling Christian internationalist enterprises that were more radical in orientation than the Christian Century but not radical enough to sit squarely with the interests of the Garland Fund. Here, the careers of Reinhold Niebuhr, Kirby Page and The World Tomorrow magazine stand out.

Both Niebuhr and Page were regular travelers on the Eddy seminar, and under Eddy both became professional intellectuals, writers and speakers, free from the responsibilities of denominational church work - a significant investment with a significant return for Christian internationalism. Niebuhr's story is comparatively well known, thanks in part to the considerable revival his legacy has enjoyed in recent years..$^{91}$ But it is important to note that it was Eddy's money and negotiation that brought Niebuhr to New York from Detroit in 1928, enabling him to join Page on the editorial team of The World Tomorrow, while teaching "Social Ethics" at Union Theological Seminary. ${ }^{92}$ Eddy played a considerable role in facilitating Niebuhr's transition from Detroit pastor to New York-based public theologian and commentator on foreign affairs.

88 On the Fellowship for a Christian Social Order see Harold E. Fey, ed., Kirby Page, Social Evangelist: The Autobiography of a 2oth Century Prophet for Peace (Nyack, NY, 1975), 99. Eddy published the founding principles of the FCSO in Facing the Crisis, 233-4, including the quotation on "mutual counsel" etc.

89 Coffman, The Christian Century, 59-69.

90 Gloria G. Samson, The American Fund for Public Service: Charles Garland and Radical Philanthropy, 1922-1941 (Westport, CT, 1996).

91 Works are too numerous to list here, but see Paul Elie, "A Man for All Reasons", Atlantic Monthly, 300/4 (Nov. 2007), 82-96.

92 Richard Wightman Fox, Reinhold Niebuhr: A Biography, with a New Introduction and Afterword (Ithaca, NY, 1996), 105. 
By providing financial support to Kirby Page, though, Eddy shaped the career of a figure less famous today than Niebuhr, but one who was in his time a very significant leader of interwar Christian internationalism. Eddy and Page's partnership began in the YMCA during World War I when Page was briefly employed as Eddy's personal secretary. After the war, Eddy employed Page as research assistant and co-writer before assuming the cost of his entire salary in the early $1920 s .{ }^{93}$ Based in a shared office at the national YMCA headquarters in New York City, Eddy and Page quickly became leaders in the army of "irrepressible pamphleteers", as colleague Devere Allen lampooned them. ${ }^{94}$ Together-at rapid clip-they co-authored booklets such as The Abolition of War: The Case against War and Questions and Answers Concerning War, and Danger Zones of the Social Order: Facts Concerning Economic, International, Racial, Political and Moral Problems - both part of their Christianity and World Problems series of books. ${ }^{95}$ As part of their anti-imperialist campaigning, they took it upon themselves to re-publish Moorefield Storey and Marcial P. Lichauco's The Philippines and the United States (1926), enclosing a petition urging the federal government to stop equivocating and to set a firm date for full Filipino independence..$^{96}$

At the heart of the Eddy-Page publishing enterprise was an operation which extended the anti-imperialist campaign to its fullest: the pre-eminent radical Christian periodical of the period, The World Tomorrow. ${ }^{97}$ When Eddy was called upon to use his finances to rescue the journal from almost certain closure in 1926 (it had been founded by Norman Thomas in 1917, but was nearing bankruptcy) he was able to take control of its direction, installing as his editors of choice

93 Page, Social Evangelist, 150. Eddy remained Page's primary financial support throughout the 1920 and 1930 .

94 Devere Allen, “The Irrepressible Pamphleteers", The World Tomorrow, Dec. 1926, 272-3.

95 Sherwood Eddy and Kirby Page, The Abolition of War: The Case against War and Questions and Answers Concerning War, Christianity and World Problems Series, No 7 (New York, 1924). Eddy and Page, Danger Zones of the Social Order: Facts Concerning Economic, International, Racial, Political and Moral Problems, Christianity and World Problems Series, No 11 (New York, 1926).

96 On the re-publication of Moorefield Storey and Marcial P. Lichauco's The Philippines and the United States, see Page, Social Evangelist, 87.

97 David Shannon's history of the Socialist Party of America identified The World Tomorrow as the "leading journal of liberal Christianity and Christian-motivated political radicalism". David Shannon, The Socialist Party of America (New York, 1936), 191. Peace movement historians Charles Chatfield and Charles DeBenedetti called it called it "the foremost exponent of the Social Gospel”. Charles Chatfield and Charles DeBenedetti, "Introduction", in Chatfield and DeBenedetti, eds., Kirby Page and the Social Gospel: An Anthology (New York, 1976), 13-36, 14. 
first Kirby Page, and from 1928 Reinhold Niebuhr. ${ }^{98}$ In its monthly and later weekly formats, the magazine aimed at building and mobilizing an oppositional voice in foreign-policy debate: its readers were to be armed with independent information while its editors remained staunch in their critiques of American militarism, nationalism and imperialism. Special themed editions in 1926 and 1927 on imperialism and militarism featured activists, scholars and internationalists from America and overseas. ${ }^{99}$ Prominent names in these editions and others included Mahatma Gandhi, Albert Einstein, John Dewey and British prime minister Ramsay MacDonald. It is hard to conceive of Page gathering such names in the independent monthly magazine were it not for the network of relationships sustained by Sherwood Eddy's Traveling Seminar.

\section{CONCLUSION}

Looking back from the 1950s, Reinhold Niebuhr recounted that he "could enumerate at least a dozen enterprises in which Sherwood Eddy gave leadership, and enlisted the services of men who were probably intellectually his superiors but who were willing followers." ${ }^{100}$ Niebuhr's remark captures what is perhaps the most important aspect of Eddy's contribution to American intellectual history. In enlisting others, Eddy fostered a pre-theoretical space for the development of Christian internationalism - a space in which later theorists, such as Niebuhr, gained their exposure to international affairs. The space consisted in the concrete enterprises and practices that Eddy convened, such as the Traveling Seminar, which positioned intellectuals like Niebuhr to be able to observe international politics up close. It consisted also in Eddy's funding and fostering of publishing ventures such as The World Tomorrow and the writing careers of Page and Niebuhr. It consisted too in the discursive framing common to these enterprises, which construed "international relations" as a category of reflection for ecumenical Protestants. But most importantly, this pre-theoretical space consisted in an outlook - a theological, political and intellectual orientation-that interpreted international relations not merely by reference to war, peace and international organization, but in light of a wider set of commitments about human intergroup relations that centered on opposition to racism, imperialism and Christian

98 The incumbent president of the journal, John Nevin Sayre, deliberately courted Page and Eddy as a last hope for the journal. See John Nevin Sayre to Grace Hutchins, 19 May 1926, 1, in Devere Allen Papers, Swarthmore College Peace Collection, DG 53, Series C-4, Box 2.

99 See, for example, the Oct. 1926 edition on "Militarism in the U.S.A.", the Feb. 1927 edition on "The Philippines and the United States" and the May 1927 edition on "The Caribbean".

100 Reinhold Niebuhr, "Introduction”, in Eddy, Eighty Adventurous Years, 10. 
nationalism at home and abroad. Such an orientation owed its origins to the missionary enterprise.

The character of Eddy's Christian internationalism does not fit conventional narratives of the interwar period-narratives that either reify the opposition of pacifism and realism, or that retell the "rise and fall" of the legalist and institutionalist internationalisms surrounding the League of Nations or KelloggBriand pact. Eddy did profess a kind of pacifism between the mid-1920s and the late 1930 s but it did little to determine the shape or the career of his internationalism. In the Abolition of War, co-authored with Kirby Page in 1924, he announced his "renunciation" of war and his support for the contemporary Outlawry of War campaign. Like Page, Eddy focused on juxtaposing the horrors of modern war with the historical Jesus, with no reference to the strength or weakness of traditional just-war theories. ${ }^{101}$ But while his pacifism may have heightened the sense of oppositionality toward the state in his writing, it did not generate his basic internationalist commitments; these were already in place. By the end of the 1930s, like many in his network of Christian socialists (most famously Reinhold Niebuhr), Eddy concluded that his pacifism had not adequately accounted for scenarios such as Japan invading Manchuria, Italy invading Abyssinia and Germany invading Czechoslovakia. Explaining this in his 1955 autobiography, Eddy offered an unattributed but distinctly Niebuhrian take on the need for "pragmatism" and the impossibility of applying an "absolute ethic" such as pacifism to present-day war. ${ }^{102}$ But none of this altered the basic shape of Eddy's internationalism. None of it, for example, explained why Eddy, with others (including Niebuhr), privately invested in an interracial cooperative farm in segregated Mississippi in 1936. Nor does it explain the way Eddy leveraged his missionary-internationalist status in efforts at cultural diplomacy between Japan and America throughout the 1930s. ${ }^{103}$ Although they are elements of the story, pacifism and realism cannot serve as the master categories through which to interpret the character of Christian internationalism.

With its roots in the missionary enterprise, interwar Christian internationalism also had an intellectual history distinct from that of other internationalisms of the period. To be sure, like liberal internationalism, Christian internationalism was implicitly defined as an alternative to communist internationalism. And, like liberal internationalism, Christian internationalism was suffused with a cosmopolitanism that, though unacknowledged, owed

101 Sherwood Eddy and Kirby Page, The Abolition of War (New York: George Doran edition, 1924), 13-77.

102 Eddy, Eighty Adventurous Years, 104-6.

103 See Jon Thares Davidann, Cultural Diplomacy in U.S.-Japanese Relations, 1919-1941 (New York, 2007). 
some debt to Kant's vision of "perpetual peace". ${ }^{104}$ But unlike mainstream liberal internationalism, missionary-rooted Christian internationalism was distinguished by its lack of focus on international law and international institutions. Its protagonists stressed instead cultural causality in international relations and the importance of non-state, person-person international relations. Here their approach reflected the influence of the missionary experience that had positioned them as agents of cultural diplomacy and of non-state international relations by definition. Retaining this orientation, interwar Christian internationalists insisted throughout the 1920s-1940s that cultural relations - especially race relations - were constitutive of international relations, the domestic intertwined with the global. On this they sounded more like W. E. B. Du Bois than conservative internationalists in the international-law tradition, for whom international relations meant regulating conduct between discretely defined nation states. ${ }^{105}$

Christian internationalism's impact is not best seen by examining specific influences on particular policy issues, whether the League of Nations or intervention in World War II-as important as such connections may have been. International historian Cecelia Lynch rightly argues that the most significant measure of a social movement's "success" is not its immediate policy impact but its capacity to legitimize ethical norms in public discourse over decades. Interwar movements had their greatest effect after 1945, she argues. ${ }^{106}$ So too with the Sherwood Eddy line of Christian internationalism. With its development of new enterprises devoted to producing Christian reflection on international relations; with its holistic and oppositional focus on racism, imperialism and nationalism in global politics; and with its sustained repugnance of Christian nationalism, it permeated ecumenical Protestant thinking from the 1920 s to the 1960 . From the heyday of Eddy's early influence after World War I through to the peace-planning conferences of the World War II, in which Presbyterian John Foster Dulles came to prominence, it was the missionary-connected internationalists, notes David Hollinger, who "inspired the most forceful of the pre-1960s anti-imperialist,

104 Immanuel Kant, "Toward Perpetual Peace: A Philosophical Sketch”, in Immanuel Kant, Pauline Kleingeld, Jeremy Waldron, Michael W. Doyle and Allen W. Wood, Toward Perpetual Peace and Other Writings on Politics, Peace, and History (New Haven, 2006), 67-109.

105 Compare W. E. B. Du Bois on the global dimensions of the "problem of the color line" in The Souls of Black Folk (New York, 1903) and Thomas Knock's discussion of "conservative internationalists" in To End All Wars: Woodrow Wilson and the Quest for a New World Order (New York, 1992).

106 Lynch, Beyond Appeasement. See the "Introduction" for discussion of criteria for success. 
ant-racist writings ... to come out of ecumenical Protestantism." 107 While much recent historical attention given to the ecumenical influence on American culture has focused on its mid-century manifestations-from the 1940s to the 1960sSherwood Eddy's story alerts us to the importance of the 1920 in setting the tone for what was later to come.

107 David A. Hollinger, "Afterword and Commentary: Religious Liberalism and Ecumenical Self-Interrogation”, in Leigh Eric Schmidt and Sally M. Promey, eds., American Religious Liberalism (Bloomington, 2012), 374-86, 385. 